\title{
Narative Analysis of Perindo Party Advertisement
}

\author{
REDI PANUJU \\ Dr Soetomo University, Indonesia
}

\begin{abstract}
This article reviews the advertisement of the Unity Party of Indonesia (Perindo), which has been repeatedly broadcast on four private television stations owned by the Party Chairman (MNC TV, Global TV, RCTI and iNews TV). The Indonesian Broadcasting Commission (KPI) prohibits advertising on the street that is excessive enough to disturb the public interest. Advertising ads are thus uploaded through social media (YouTube). In the ads, the figure of the general chairman, Hari Tanoesoedibjo (HT), is very dominant to form a party control image. It seems that HT's ambition is to use the party as a tool to achieve political power. There is no prohibition for every citizen to rule in this country, but the political reality still has sentimental opinions based on ethnic identity. Meanwhile, HT has an ethnic Chinese descent. Thus, it is possible that the public will respond to Perindo's advertising negatively. This review recommends technical changes to advertising messages, use of different TV stations, and presents other figures outside of HT to give Perindo the impression of an open party. The method of analysis of this article uses the narrative analysis i.e. Graimas model, who tried to interpret the text as a tool to strengthen a certain figure with a profile relevant to the general or intended audience.
\end{abstract}

Keywords: Advertising effectiveness, Tanoesoedibjo day, narrative analysis, Perindo advertisement, social media.

\section{INTRODUCTION}

The Unity Party of Indonesia (Perindo) is one of the new parties in Indonesia that is ready to join the legislative selection. Originally, this party started in the form of a social organization that in Indonesia is known by the term 'Ormas. This organization is engaged in populist economic, education, youth, and sports fields. In the field of populist economy for example, Perindo tried to recruit people from low-classes to do entrepreneurship by using charts labeled with Perindo. Perindo also provides ambulance that is intended for people to go to the hospital in an emergency situation. Other Perindo activities are futsal sport competition, which the Hary Tanoesoedibjo trophy is competed for. Charts, ambulance, and futsal appear on news on television, a broadcasting station owned by Hary Tanoesoedibjo (HT). By 2015, these ormas were transformed into political parties.

The Unity Party of Indonesia (Perindo) was founded by Hary Tanoesoedibjo (HT) on February 7, 2015. Before deciding to establish its own political party, HT was known as a top entrepreneur in Indonesia who has a lot of business activities, ranging from investment management, banking, and retail (modern retail kiosk), to the media business (television, radio, print media, and on-line media). In 2011, Forbes magazine released the list of richest people in Indonesia, and Hary was ranked 22nd with a total worth of US $\$ 1.19$ billion. By 2017, Forbes estimates Hary Tanoe's wealth at US \$1.8 billion, about Rp 14.5 trillion (Steffi, 2017). 
The reason HT established a political party as quoted by "okezone.com" (an online media of his own) is that he wanted to build Indonesia in many different sectors, so he must be involved in politics in order to be able to achieve his future goal of building the nation. The opinion of Mr. HT is that a nation cannot be built by only giving money to the society. "Through political parties we can build a nation," said Armyn. Armyn explained that in order to build Indonesia, it takes policies that can only be made if someone is in government (Prasetyo, 2016). It is known that an entrepreneur will be protected if they become a politician. In fact, this is not a monopoly of HT, because previously successful entrepreneurs are also eager to enter politics such as Aburizal Bachri, M. Yusuf Kalla, Surya Paloh, Sutrisno Bachir and Joko Widodo aka Jokowi (President of Indonesia now, formerly known as a wooden furniture merchant).

Yahya A. Muhaimin (1990) has exposed a conspiracy between entrepreneurs and government in mutually supportive businesses. The government needs investment and entrepreneurs need protection, so in many ways the government, during the New Order's reign, provides convenience to Indonesian businessmen to develop their business. In the era of Soeharto's regime this model is often called a business conglomerate. The economic is growing but only certain people control ownership. Although the era of government has changed, the business collaboration model with power remains a reference. Businessmen feel less secure about their business if they do not have access to real power. Therefore, it is natural for many Indonesian businessmen to join politics.

HT will be able to develop Perindo freely to all over Indonesia. HT's profile, which has a lot of broadcasting media, makes it easier to introduce his party to the public. There are three television media outlets owned by HT that are often used to display Perindo ads, namely: RCTI, MNC, and Global TV.

Data from Adstensity - a platform that calculates and analyzes advertising data on television - has recorded for the last three months, starting from November 2015 to January 2016, that Perindo party advertising on MNC Group occurred 1918 times. The details of the advertisement are RCTI (648 times), MNCTV (630 times) and Global TV (640 times). Based on the calculation of Adstensity, the value is around Rp 132 billion. Perindo's political ads are shown on programs that many viewers watch. For example, In RCTI, Perindo ads that often appear are not running during prime time, but still have a fairly high viewer rating. Even so, often during prime time, on the sidelines of the Anak Jalanan and Tukang Bubur Naik Haji soap operas, Perindo ads often appear (Tirto.Id, 2016). In the next period, Perindo Ads are also played on other TV stations that belong to HT, like iNews TV.

In Indonesia, the issue of centralizing the ownership of broadcasting media (radio and television) is one of the things that should be avoided because it is feared that it will affect the uniformity of broadcast content. In the broadcasting law (Act No. 32 of 2002), article 18 paragraph 1 states that concentration of ownership and control of private broadcasters by one person or one legal entity, in one broadcast area or in some broadcasting areas, is limited. The philosophy is that the monopoly of broadcasting is on the one hand feared to diminish the right of others to organize broadcasting, thus contradicting the principle of democracy that every citizen has the same status in law and government, and is also feared to monopolize the formation of public opinion in society. If public opinion is used for a personal or a group purpose, it will be feared to create a conflict in the society. From the perspective of the content, the centralization of ownership will potentially reduce the citizens' right to choose 
broadcast content to watch in accordance with their wishes, preferences, or needs. Thus, the law that regulates television in Indonesia has been concerned with the principle of democracy, namely to build a television system that avoids a monopoly, resulting in diversity of ownership. Indeed, diversity of ownership is expected to result in diversity in the content of the broadcast.

But in fact, even though the law has been in existence for 15 years, television in Indonesia cannot be separated from the tendency of media conglomeration. When the media monopoly is linked to the content of politics, people begin to feel the discomfort. Moreover, for people who have different political ideologies, the discomfort is expressed in the form of protests. The protest is of course not delivered through the four TV stations owned by HT, because it must be ignored. The protests have been broadcasted through the Indonesian Broadcasting Commission (KPI), an independent institution established specifically for the mandate of broadcasting law to monitor the content of the broadcast.

There was also another protest in the form of petition movements, which was exposed through social media. The movement to make the petition was, for example, performed by Szabila A. Widyantari who had started this petition with one signature and now has 53 supporters. Start a petition today to change something you care about (Widyantari, 2017).

Based on the information from the society, finally, KPI gave a warning to RCTI, MNC TV, I-News TV and Global TV related to the intensity of Mars Perindo advertisement which was considered unusual on Monday, October 17, 2016. According to KPI's explanation in the warning letter to four television stations, ad impressions with a payload of Perindo Party potentially disrupt public convenience due to the excessive intensity of the airing (Komisi Penyiaran Indonesia, 2016).

Perindo's political advertisements have generated a reaction of rejection from the public. This is particularly true for the advertisement where HT could be seen along with his mass depicting the enthusiasm of advancing the society, and HT's picture was in the middle of farmers who were harvesting rice, as well as alongside fishermen who were carrying fish, merchants who were serving their buyers, and also with the santri (muslim student) in pesatren (Islamic boarding school) who were listening to his sermon (HT was also wearing complete Muslim-style clothing with a black cap). The visual illustration is accompanied by Perindo's mars. The lyrics of the mars are:

Let all the people of Indonesia

Look ahead

Grab your dream for the nation

Unite your determination for the future

Abstinence is your guideline

Reduce poverty is your future goals

Obstacles do not frighten you

Indonesia prosperity is your goal

Light the fire of the fighting spirit

Echoing echoes of unity 
By PERINDO... by PERINDO...

Be glory Indonesia!

(Triyono, 2017-05-13)

Perindo Mars is said to be memorized by many people because of the frequent viewing and listening. People get worried especially when Perindo Mars is memorized by children because the mars is played on a children's television program. A journalist compiles the form of violence as follows:

\section{Children Memorize Perindo Mars Instead of Short Ayah in Al Quran}

Thursday, May 18, 2017 18:56

\section{Special}

WARTA KOTA, JAKARTA - The popularity of the Perindo Party mars among children is being feared by parents. At least, it happened in Semarang regency, Central Java.

Parents generally do not want their children to memorize something that is not considered appropriate for children.

"My son, Syafiq, first grade, it is difficult to ask him to memorize short surah (Al Quran), but suddenly he clearly memorized Perindo mars," said Indri, housewife, Citizen Ungaran Timur, Tuesday (2/2/2016).

Similar to Indri, Sujiono, a resident of Kalirejo, also admitted surprised to find his son often sings Perindo mars in between playing activities.

"Not clearly memorized, but he knows the exact tone that is showed on television," said Sujiono, father of Farhan, Istiqomah kindergarten student, Ungaran.

Diana, mother of two children who still sit in kindergarten and grade 1 elementary school, citizen of Villa Krista, Ungaran, also admitted being worried with her son who often sings Perindo mars. His youngest son has already memorized it.

According to Diana, her son knew the mars because he often heard the song played on television. "How can you not memorize it?" said Diana.

Indri, Ali, and Diana both suspect that the phenomenon of boys who memorized the mars of a party is because they often watch certain television channels that air the cartoon series.

They claimed they could not prevent their child's habit because they were addicted to watching cartoons.

"Incidentally, a lot of children's films are being broadcasted on the channel, but again, it is wrong that children are singing party songs," said Indri.

Responding to the phenomenon of children memorizing Perindo mars, the Head of Semarang Kesbangpolinmas office, Purbin Purbatin Hadi said, there is no rule or law that prohibits a television show party marses. 
However, if it is considered harmful, the Indonesian Broadcasting Commission (KPI) should immediately take action.

"Perindo is an official mass organization, which should be limited to the use of media, so the KPI should be more assertive, especially since there are already complaints from the public," Purbatin said. (wartakota.tribunnews.com/2017/05/18)

Later saw the emergence of videos on YouTube and social media, containing elementary school children who sang Perindo Mars (Purbasari, 2016) as in Figure 1.

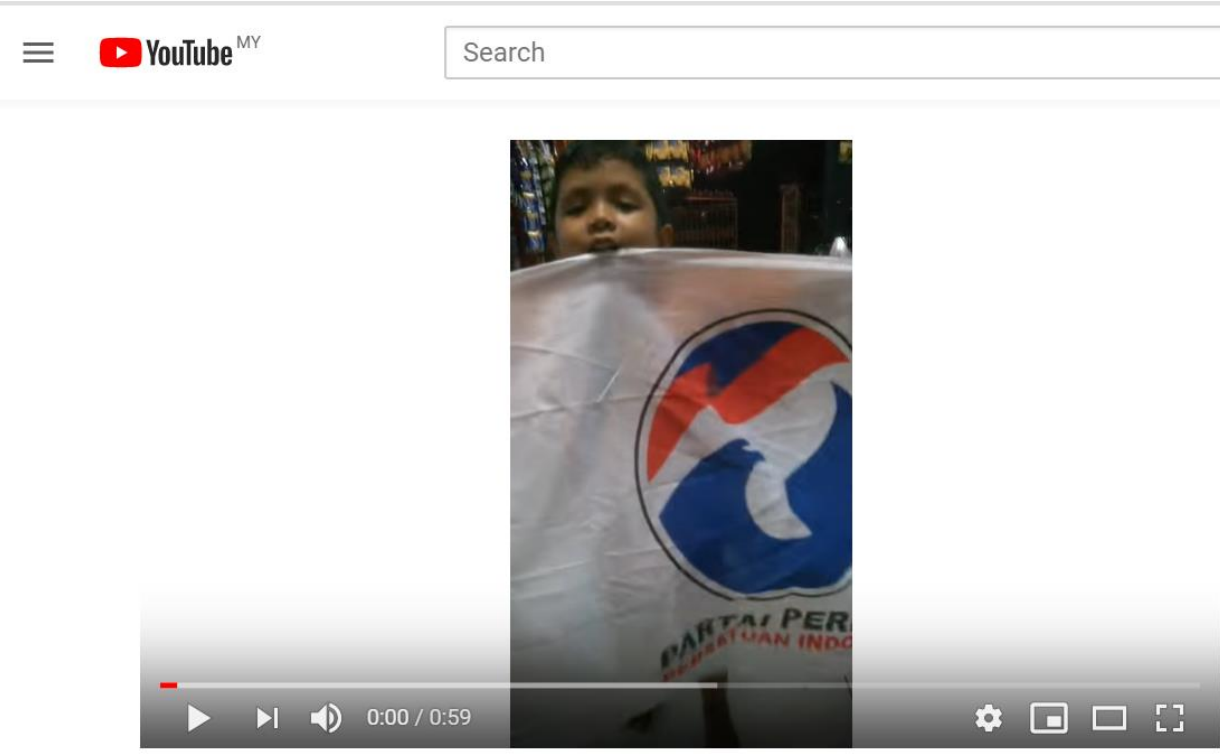

Mars Perindo Cilik

64,846 views · Published on Feb 6, 2016

II $50 \rightarrow$ SHARE 57 SAVE $\ldots$

Figure 1: Children singing Perindo Mars

Source YouTube: https://www.youtube.com/watch?v=ZnB1OaP-4kE

\section{LITERATURE REVIEW}

Is it wrong for HT to show ads on television? From several literature sources it can be explained that many worthy arguments become the reasons for HT's political actions. Marcel Danesi (2002, 2010, p.222) argues that advertising is no longer merely a fulfillment of commercial interests. Instead, advertising has become a common strategy that everyone uses to persuade others through something: for example, promoting a political candidate, supporting a common goal and so on. They regularly advertise in various media to create their own "image" in people's minds.

Image is anything that the senses see, but actually does not have a substantial existence. Humans, according to Baudrillard (Piliang, 1998), live in an artificial world (created, manipulated). Television has manipulated everything into a sign or system code. Through that 
code, humans combine socially agreed signals to enable a message to be transmitted from one person to another (Piliang, 1998, p.13), (Sugihartati, 2014, p.168). In other words, television has built its own reality according to construction, while the reality that is not constructed by the media fails to be marked as reality. Therefore, audiences give meaning to something from the television following a sign that is highlighted, repeated (reproduction), and given special pressure (stressing).

Why is Perindo's political advertising focused on television? Danesi (2010, p.173) illustrates it in the United States, where television news has a pretty good effect on electoral politics and public opinion. For example, in 1960 the presidential candidates Richard M. Nixon and John F. Kennedy agreed to conduct a debate that was broadcasted simultaneously on television and radio. According to some surveys, most of the radio listeners felt that Nixon won the debate, while television viewers chose Kennedy. And it turns out Kennedy won the election the following autumn. This shows the strength of the visual image of all the signs.

As stated by Baudrillard in Piliang (1998) (Television news of the Vietnam War (19591975) encouraged the transformation of US political policy. For the audience the horror captured from the television broadcast was so emotionally disturbing that it led to a full coverup of optimistic reports about the victories that would occur and announced by government officials via radio and papers. Danesi $(2010$, p.221) cites the results of a study by Kilbourne (1999), which states that the average American person sees more than 3000 (three thousand) ads per day and watches television commercials for three years throughout their lives.

According to Deddy Mulyana (2013, p.22), in the future political communication will be more interesting, because the mass media - especially television, newspapers, and the Internet - will be the main media in improving the image of self-politicians. Morison states that TV has many advantages over other types of media. It covers a broad reach, has selectivity and flexibility, focuses attention, creativity and effects, prestige, and certain time (Marison 2015, p.240)

Through the television media, various techniques of political advertising can be made. Brian McNair (2011) in Mulyana (2013, p.82-85) said that there are 8 (eight) categories of TV advertising techniques: first, primitive ads, usually artificial, rigid, and make the candidate known. Second, talking heads, designed to highlight the issue and convey the image that the candidate can handle the issue. Third, negative ads, which tend to attack the policies of candidates or opposing parties. Fourth, the concept ad, designed to illustrate the idea of big and important ideas about the candidate. Fifth, cinema-verite ads, techniques that use informal and natural situations. Sixth, advertising testimonials, both from ordinary people and prominent figures. Seventh, neutral reporter, involving a series of reports on candidates or their opponents and member opportunities for viewers to assess. And lastly, eighth, transfers device, using a certain character as they have a close relationship or are familiar with the candidate.

Technically what Perindo does by connecting the broadcast media with "The New Media" is also not wrong, because the reality between mass media and cyber is no longer inevitable. Perindo's political ads, in addition to being played on four of HT's TV channels, are also uploaded in online media or responded to on online media. Public response through the online media is the result of a closed public access to HT's TV media, because the criticism of TV commercials that advertise Perindo's political ads is equivalent to negating the promotional and imaging values that political advertising aims for. Connectivity between TV and online media 
means a multiplication of information and increases the frequency of messages exposed to the public.

Cyber media used by HT include sites (websites), wikis, and social media. In the literature, the website is a page that has a domain address that contains information, data, visual, audio, loading applications, and contains links from other webpages. A wiki is a site that collects articles and news according to a keyword. Similar to dictionaries, a wiki brings to users some sense, history, to book references or links about a single word. In practice, this explanation is done by the visitors. Social media or social networking (social nerworking site) is a media used to publish content such as profile, activity, and others, as well as a media that can be used for communication and interaction. In this case, Perindo is using Facebook (Nasrullah, 2014, p.25-36).

The use of mass media of television, mass media and social media by Perindo in its political advertisement can be explained through the internet politics function scheme written by Jan Van Dijk (2012, p.104-105), which involves the internet as a tool of democracy. Van Dijk distinguishes that the function of the internet in the political context contains two problems, which are freedom or control. In Indonesia these two functions go hand in hand. Both mass media and social media live in an atmosphere of freedom, but at the same time there are country interventions to control it in order to protect public interests or public order. At the mass media level, the country controls the television media through the monitoring of broadcasting contents whose implementation is carried out by an independent institution called the Indonesian Broadcasting Commission (KPI), with KPI in the center (based in Jakarta), as well as in regional areas based in the provincial capital called the Regional Commission Indonesian Broadcasting (KPID). The authority to control the content of broadcasts is provided by Act No. 32 of 2002 on broadcasting. Meanwhile, at the social media level, the country also has the authority to control the content of the content according to the Act No.11 of 2008 on Information and Electronic Transactions (ITE), then revised into Act No. 19 of 2016 which essentially governs cyber users not to produce, reproduce or disseminate contents containing pornography, humiliation and defamation, threats of violence, hate speech, terrorism, and so forth.

Perindo Party's political ads have been controlled by KPI so that at a certain time they are not allowed to be played. Thus, it is fair that after being unable to advertise on television, they had the possibility to upload on social media and YouTube, because for a political party advertising is a bridge (media) to communicate with the people. Thus, it can be said that the social media used by Perindo serves its advertisement as a "continuation" of the functions that has stopped in the mass media of television. Or, according to Danesi (2010, p.251), today's digital galaxy is actually an extension of the Gutenberg galaxy. Communities are given the option of selecting media that suits their objectives, which are considered appropriate to their target audience, and in the context of Perindo's advertising that allows political messages to remain reaching the public. 


\section{METHODOLOGY}

This study uses a narrative analysis. Littlejohn $(2009$, p.673) states that narratology is a study and narrative theory, or complex story - what its shape is, how it is structured, and what we get from using it as a medium of communication. Narratology has its beginnings in studying literary texts. From literary analysis, the text term has been extended to anything, not just writing or lettering. Thus, open narrative analysis of interpretation.

Nasrullah (2014, p.187) states that one of the techniques that can be used in viewing the phenomenon in cyber media is narrative analysis. Narrative analysis is defined as an attempt to reread two or more situations that are logically related, both in terms of time and place, and related to the consistency of a subject of the whole text or message to see the narrative or story change of the sign; including to reveal the hidden meaning of the sign. Following the opinion of Greimas states the narrative emphasizes the role of the form of signs (actant) which in a work of fiction is represented by the figure of the main character in the transition of meaning (Nasrullah 2014).

Perindo Party's political ads are no different from fictional works in which there are stories, characterizations of HT figures, surrounded by various signs (text or images). Therefore, the technique of narrative analysis becomes relevant when presented for the characterization description in the storyline (HT). According to Greimas in Nasrullah $(2014$, p.188) the characterization image in the actant has six characteristics: (1) determining direction; (2) the text is also interpreted as the receiver because it carries the value that constructed by the creator of the text; (3) the text is also the subject which has the main role in narrating the message to be delivered; (4) the text becomes a representation of the goal; (5) the text is a supporter (adjuvant) that helps the subject to achieve the goal; (6) there is always a traitor that can obscure the purpose of the text to be delivered.

This characteristic is an actantial Mythical Model that explains how the narrative displaces the meaning of a text; relationship and direction of actant as shown in the following Figure 2:

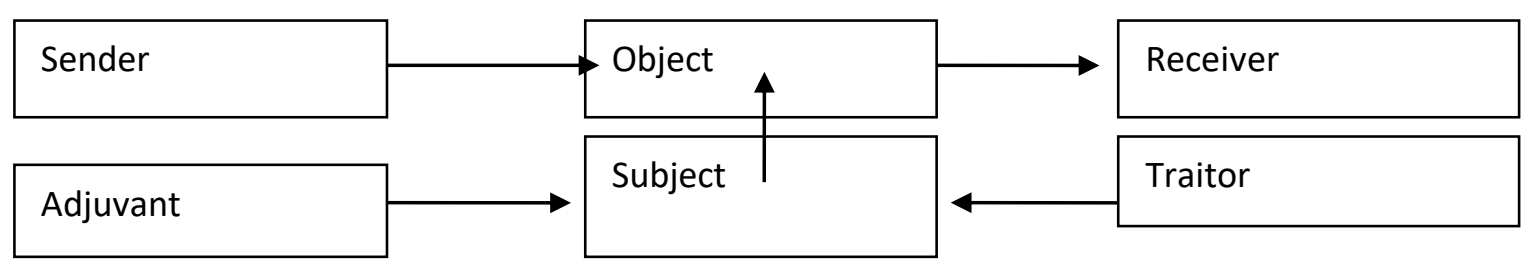

Figure 2: The Actant Greimas Model in Nasrullah (2014, p.188)

Perindo's political advertising objects to be reviewed include Perindo ads that are uploaded on YouTube as follows:

https://www.youtube.com/watch?v=UNNLDP6vKpQ uploaded on Mars 29, 2015 (1) https://www.youtube.com/watch?v=U6FHEHUEGol uploaded on November 9, 2015 (2) https://www.youtube.com/watch?v=S2ctrpd1f_U uploaded on December 1, 2015 (3) https://www.youtube.com/watch?v=dxE7S3-k17g uploaded on June 8, 2016 (4) https://www.youtube.com/watch?v=ppEX21imHsk uploaded on August 1, 2017 (5) 
The four forms of Perindo Ads above were played on television until finally terminated by the Indonesian Broadcasting Commission (KPI). In July 2017 Perindo uploaded the news about Perindo preparation in facing the verification of the General Election Commission (KPU) and uploaded them on YouTube on August 1, 2017.

The focus of this study is on Perindo's political advertisements that establish HT as the subject that conveys the party's vision and mission as an object. In achieving that goal, it is packed in visual and supporting texts (adjuvant) and its resistance barrier (traitor).

\section{ANALYSIS}

Visual and Text

In advertisement (1), HT as the head of the Perindo Party is delivering a speech in front of his sympathizers (supporters) containing the concept of party vision to make the developed country: requires greater economic growth but at the same time it touches and provides benefits to the economically weak community. In general, they are small businesses, farmers, fishermen, laborers, unemployed, and other community groups such as the teacher. So far, we (Indonesia) are too focused on macroeconomic growth and pay less attention to the distribution of the growth. We want the quality of life of a more decent and dignified society. The speech ended with a shout of Perindo Party for a prosperous Indonesia!

Throughout HT's speech, it shows pictures of farmers harvesting rice, working laborers, fishermen fishing, and craftsmen making their crafts. Other figures showed bright and smiling faces.

In ad (2), it shows the profile of Indonesian people with traditional clothing from various tribes and clothing that show the identity of various religions and profiles like the middle economic class (wealthy people) and lower middle class (poor people).

This visual ad wants to show cultural diversity, religious, geographic, and socioeconomic status. Supporting text: Who is Indonesia? Are they born of Javanese, Dayak, Papuan, or more than 300 other tribes? Who is Indonesia? Whether they are Muslims, Catholics, Christians, Buddhists, Hindus, Confucians, or from other beliefs. Who is Indonesia? Are those who earn billions, or those who are only able to support their lives day in and day out? That's not all. Indonesia is the sincere heart lovers of this country. Those who sincerely struggle and do the real act. Perindo for Prosperous Indonesia.

In advertisement (3), there are some farmers who are harvesting paddy, the HT wives who are dabbling with the poor society, the war veterans who are leisurely bicycling, the gentle but serious HT speech, and the HT activities of distributing envelopes to the poor, opening a futsal sporting event, and greeting the merchants with a cart that reads Parindo. HT was greeted loudly by indigenous communities in Papua, ambulance cars marked Perindo, and hand clenched of HT. The text that supports Perindo's aims is the Perindo mars song that has text which has been written on the front of this article.

In advertisement (4) is HT's visualization of joining the community to greet the traders (who were successfully taught by Perindo), spreading the fish seeds in the pond, and the atmosphere of HT was in dialogue with the people, ending with HT giving speeches and clenching hands. This visualization is reinforced with text and sound (audio) of Perindo Mars. 
Advertisement (5) is in the form of news previously broadcasted by iNews TV (TV station owned by HT) and contains party management activities in various regions to prepare verification, which will be conducted by the General Election Commission (KPU) in order to pass the 2018 General Election (General Election simultaneously for position Regent / Mayor and Provincial Governor) and Legislative and Presidential Election simultaneously in 2019. The main message sent to the audience shows the scheme as in Figure 3:

Figure 3: HT Audience Show

\begin{tabular}{lll}
\multicolumn{1}{c}{$\begin{array}{c}\text { Number of } \\
\text { advertisement }\end{array}$} & Visual message & Text message \\
\hline Ads (1) & HT as the future leader & $\begin{array}{l}\text { A more decent and } \\
\text { dignified quality of life } \\
\text { Ads (2) }\end{array}$ \\
Ads (3) & $\begin{array}{l}\text { HT as a unifying figure in } \\
\text { the plural country } \\
\text { HT as a soft, generous, } \\
\text { and tolerant figure }\end{array}$ & $\begin{array}{l}\text { Indonesia } \\
\text { Perindo Mars Text }\end{array}$ \\
Ads (4) & $\begin{array}{l}\text { HT is a populist figure } \\
\text { HT is an optimistic figure }\end{array}$ & Perindo Mars Text \\
in the 2019 election & No text \\
\hline
\end{tabular}

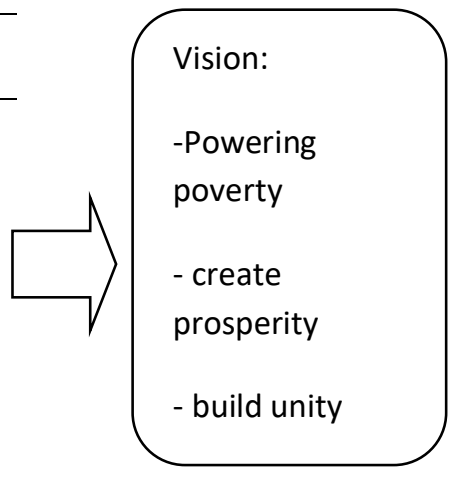

All of the above advertisements in essence convey the message that the Perindo Party has as mission to raise the level of economic life of the poor, for farmers, workers, craftsmen, fishermen, and traders. The message is as if the Perindo Party is positioned as an "opposition" party that is criticizing the existing political realities, like the government forgetting these people and being more concerned with infrastructure development such as roads, ports and buildings. Perindo's ads play as if they are criticizing governments that tend to be concerned with economic growth, while forgetting equity or justice.

\section{The Form of Sign (Actant)}

In the five ads above, some of the characteristics consistently delivered as a form of sign are shown:

1. The Perindo Party's future goal is a prosperous Indonesia.

2. The Perindo Party is a party for everyone; no matter what tribe, religion, class, social-economy status.

3. Placing HT as the sole figure that identifies Perindo is HT and HT is Perindo.

4. Perindo prioritizes the real work in the form of poverty reduction from some society group (farmers, fishermen, laborers, teachers, craftsmen, and others).

5. Unstoppable spirit (shown by HT's fist and yelling Perindo for Prosperous Indonesia).

The Perindo Party profile above is confirmed by some text and text/visual structure. Advertisements (1) through (5) show a series of socialization stages. Advertisement (1) emphasizes the concept of the party in the future and organizational values. In this advertising, this stage is known as the stage of introduction to the public; it's only a notification. Similar 
things are found in advertisement (2) that seek to concrete the ideological vision of the Perindo Party that asserts itself as a loyal party to diversity and pluralism. Then in advertisement (3) and advertisement (4), advertising has already led to branding (strengthening the party as a trademark), by indoctrinating the public with Perindo Mars. And advertisement (5) shows the stages in political communication that are convincing or even strengthening the choice. The meaning appears in the news about readiness of the party following the 2018 and 2019 elections.

$\mathrm{HT}$ figure is imaged as a leader who is both authoritative and populist. Authoritative is shown on the visualization of HT figure while giving the speech and audience paying rapt attention; HT was greeted enthusiastically by certain ethnic communities with traditional ceremonies; cinematographically when HT was speaking on the podium taken from the bottom of the picture so as to impress the structure of a higher place of the audience. A higher place shows a higher social structure; then HT led the people to shout "Perindo for Prosperous Indonesia". Meanwhile, populism is shown on the HT visualization that likes to greet the traders, fishermen, farmers, craftsmen, and so forth.

Other HT profiles that the ad wants to set up include that HT is rich but still generous and cares about others. The rich image shows HT getting off the private plane as a symbol of his possessions. Only rich people travel by private aircraft while a train of economy class, bus, or bicycle usually symbolizes the poor, whereas the generous nature of HT is visualized through for the money-filled envelope of orphans or the poor.

Furthermore, HT is also profiled as a firm but humanist figure. The figure is firmly portrayed by way of a HT that runs steadily and speaks fluently (not stuttered). The humanist is depicted as associating with all groups and wanting to interact without division with the lowclass community.

Last, HT is profiled as a figure of a harmonious family, which is depicted with the appearance of his wife in the event that was attended by HT. The wife was highlighted holding a small child in the crowd.

Thus, it can be concluded the myth that would be built by the advertisement is to strengthen the legitimacy of the Perindo Party through the figure of the leader HT, which is highlighted as a figure who is authoritative as well as a populist, a rich figure but generous and caring for others, firm but a humanist, and the figure of a harmonious family.

\section{Traitor}

The HT profile that he wants to reach through Perindo ads can be estimated for its effectiveness through text analysis that is the obstacle to the goal. Text blocker in Facebook can be tracked through comments (comment) contained on the wall upload video. The result of tracking Traitor indication of Perindo Party's political ads as follows: 
Table 2: Traitor indication of Perindo party's

\begin{tabular}{ll}
\hline Ads category & \multicolumn{2}{c}{ Traitor text findings } \\
\hline Ads (1) & "hey Hari ....... Loe do not deserve \\
& to be party chairman. You \\
& deserve to be a cheerleader"
\end{tabular}

Ads (2)

Ads (3)

Ads (4)

Ads (5)
No comment found

"Article 11 clause 1 states that "Broadcasting programs shall be used for public purposes and not for the benefit of certain groups." Report it to the KPI. This already exceeds the threshold"

"Lol Indonesia is ready to lead China, ready to become president of Indonesian republic 2019. Hary Tanoesoedibjo ready to become president of Indonesian republic 2019. The eyes narrow stronger!!! Jokowi down 2019 later..."

"People not satisfied indeed .. not enough given wealth \& family good, now want to be president Lol"

"Every time I see RCTI and then appear advertisement Perindo, then I change the other tv station because I know the direction where to the presidential election. For me Anis and Tanu are just as evil. RCTI is for everything for the event program owned by Indonesia why used the campaign. That's true cinema art, Anak Jalanan and Tukang Bubur Naik Haji soap opera on the move. It because RCTI used for things that are not good. How pity the audience, sir.."

\section{Description}

The word "loe" denotes the Betawi people dialect (Jakarta) which means "you". The narrative structure is mocking, degrading HT inappropriate as Chairman of the party, then lowering him to the level of the cheerleader (the girl who accompanies the guests in the Karaoke room).

The commentator disagrees because the advertisement is considered contradictory to Act No.32 of 2002 about broadcasting.

This shows that in Indonesia ethnic problems (ethnic) are still a consideration in choosing leaders

Perceptions of commentators that tend to be negative because HT is considered not enough to be given wealth.

The commentators questioned the private TV that should be for the people to be the campaign media of the party owner. This is considered evil. Anis means the Candidate of Jakarta Governor who was elected as Governor in the last General Election of Februbari. Tanu means Haritanoe (HT).

It is implied that the content of advertising messages gets repulsed (resistance) due to ethnic backgrounds of HT originating from Tinghoa ancestry. At the time this advertisement was broadcasted on TV and uploaded on social media, Indonesian people are facing social conflict problems of ethnic background, race and religion, i.e. mobilization of action took to the streets of Muslim society protesting the statement of Governor of DKI Jakarta at that time (Basuki Tjahjapurnama aka Ahok) who interprets the Qur'an Almaidah verse 51 letter subjective, which makes the masses feel hurt. People protested several times that the 
government need to judge Ahok. Even the Indonesian Ulema Council (MUI) released the results of its study which stated Ahok's statement was categorized as deviant.

The other resistance to the advertisement comes from a rational argument, namely the misuse of broadcasting frequencies, which should be used for public purposes such as the intellectual of the nation life, monopolized by HT to play its own party ads. In broadcasting regulations in Indonesia (Act No.32 of 2002), the broadcasting system is intended to guarantee democracy, so that broadcasting frequencies are considered as public property, therefore their utilization is regulated by the country. The law is limited to the ownership of broadcasting institutions with a view to creating a distribution of ownership (diversity of ownership). Through this concept variation of the contents of the broadcast is expected to happen (diversity of content). The public is guaranteed the right to have the right spectacle in accordance with its interests and needs. It is very unusual to know that HT has monopolized broadcasting ownership (TV) and is used to play its own party ad which makes people angry, because it shows facts contrary to broadcasting regulations.

\section{CONCLUSION}

Based on the narrative analysis of the Greimas model, it can be concluded that the Perindo Party's political advertisement was played on four private TV channels owned by Perindo Chairman and then it was uploaded on social media (YouTube) trying to follow the rules of advertising in general through the stages of socialization (information), awareness, branding, and public legitimacy. The text and visual structure shows HT's profile as the main figure of the party. HT is profiled as an authoritative, firm, populist, wealthy, generous, humanist, who comes from a harmonious family.

The obstacles that may arise from the ads cover the figure of HT that identifies as Chinese ethnic, while the political voters in Indonesia are still primordial. Religious, ethnic, and racial elements are still decisive variables in deciding political choices. Another obstacle is that HT is considered evil because using his four TV stations are used as a promotion media of his party, whereas in Indonesia in accordance with the Broadcasting Law (Act No.32 of 2002), the frequency used to broadcast television broadcasts is public property, therefore the text containing the Indonesian Broadcasting Commission (KPI) ban on Perindo ads on four HT televisions is interpreted by the public as a stigma.

\section{RECOMMENDATIONS/SUGGESTIONS}

1. To avoid the impression that Perindo's party is privately owned, Perindo's future ads should not highlight HT figures predominantly. Must be created by other figures as icons of Parindo Party.

2. To avoid the impression of the associative meaning of Perindo Party as a party belonging to peranakans (Chinese descendants), the figure of local figures should be highlighted not only as a farmer or fisherman, but also an upper-class figure in the party structure. Thus, this party will be known as a party of local people (pribumi) who can interact with peranakans such as HT. 3. The content of the story is made softer to reduce the impression contrary to the government. Some of the legal cases that ensnare HT are very likely to have political power interference to give "lessons" to HT so as not to be harsh in criticizing the government. 
4. TV stations belonging to HT should stop advertisement Perindo ads. Although advertising on the TV station itself is not prohibited, it can be a barrier (traitor) to ad messages to the audience, because the TV audience was already being critical in assessing the content.

5. If it is still wanted to advertise through television stations, it is advisable to advertise on television stations that are not his, such as TV One, MetroTV, Trans7, Trans TV, SCTV, RTI, TVRI, and Indosiar.

6. It is advisable to advertise on local TV stations that are now available in all provinces in Indonesia. For the purpose of reaching the legitimacy of audiences in the 2019 legislative elections, it would be good to use a local TV station because the message would spread evenly across the country.

\section{ACKNOWLEDGEMENT}

This research funding by DRPM Ministry of Research and the Higher Education Republic Indonesia with Grant Number: 005/SP2H/LT/K7/KM/2019.

\section{BIODATA}

Redi Panuju is the Dean at the Faculty of Communication Sciences, Dr. Soetomo University, Surabaya, Indonesia. His research interests are social media research, cinema production, and community radio. Email: redipanuju@gmail.com / redi.panuju@unitomo.ac.id 


\section{REFERENCES}

Danesi, M. (2010). Pengantar memahami semiotika media. Jakarta: Jalasutra Komisi Penyiaran Indonesia (KPI). (2016). Retrieved from www.kpi.go.id/index.php/lihatsanksi/33605-peringatan-tertulis-untuk-program-siaran-iklan-partai-perindo-mnc-tv

Littlejohn, S. W. (2009). Encyclopedia of communication theory. California: SAGE Publication. Morison. (2015). Periklanan: Komunikasi pemasaran terpadu. Jakarta: Prenada Media Group.

Mulyana, D. (2014). Komunikasi politik politik keomunikasi: Membedah visi dan gaya komunikasi praktisi politik. Bandung: Remaja Rosdakarya.

Muhaimin, Y. A. (1990). Bisnis dan politik: Kebijaksanaan ekonomi Indonesia 1950-1980 (Terjemahan Hassan Basari \& Muhadi Sugiono). Jakarta: LP3ES.

Nasrullah, R. (2014). Teori dan riset media siber (Cybermedia). Jakarta: Prenada Media Group.

Prasetyo, E. (2016, November 26). Alasan Hary Tanoe dirikan perindo disampaikan saat pelatihan kader di binjai. Retrieved from https://news.okezone.com/read/2016/11/26/340/1552251/alasan-hary-tanoedirikan-perindo-disampaikan-saat-pelatihan-kader-di-binjai

Piliang, Y. A. (1998). Sebuah dunia yang dilipat, realitas kebudayaan menjelang milenium ketiga dan matinya postmodern. Bandung: Mizan.

Purbasari, S. (2016, Februari 19). Juara1 Mars partai parindo. YouTube. Retrieved from https://www.youtube.com/watch?v=EdBPtgb-azs

Sugihartati, R. (2014). Perkembangan masyarakat informasi dan teori sosial kontemporer. Jakarta: Prenada Media Gorup.

Teowira, S. (2017, Februari 02). Obtained from http://www.qerja.com/journal/view/5739berapa-nilai-kekayaan-hary-tanoesoedibjo/

Tirto.Id. (2016, Februari 15). Menancapkan Mars Perindo melalui stasiun TV pribadi (on-line). Retrieved from https://tirto.id/menancapkan-mars-perindo-lewat-stasiun-tv-milikpribadi-nn

Triyono, H. (2017, Mei 29). KPI hentikan Mars Perindo berkumandang (online). Obtained fromhttps://beritagar.id/artikel/berita/kpi-hentikan-mars-perindo-berkumandang

Van Dijk, Jan. (2012). The network society (3rd ed.). California: SAGE Publications Ltd.

Wartakota Tribunews.com. (2017, Mei 18). Anak anak lebih hafal Mars Parindo daripada surat pendek di Al-Qur'an. Retrieved from http://wartakota.tribunnews.com/2017/05/18/anak-anak-lebih-hafal-mars-perindodaripada-surat-pendek-di-al-quran (media on-line)

Widyantari, S. 2016. Mempetisi KPI. Retrieved from https://www.change.org/p/kpi-lanjutkantindakan-tegas-kpi-terhadap-penayangan-iklan-mars-perindo-di-saluran-tv-mnc-grup (on-line)

\section{YOUTUBE}

https://www.youtube.com/watch?v=UNNLDP6vKpQ uploaded on Mars 29, 2015 (1)

https://www.youtube.com/watch?v=U6FHEHUEGol uploaded on November 9, 2015 (2)

https://www.youtube.com/watch?v=S2ctrpd1f_U uploaded on December 1, 2015 (3)

https://www.youtube.com/watch?v=dxE7S3-k17g uploaded on June 8, 2016 (4)

https://www.youtube.com/watch?v=ppEX21imHsk uploaded on August 1, 2017 (5) 
Regulation etc: ITE, KPI.

\author{
ABREVIATION \\ DKI = Daerah Khusus Ibukota \\ DRPM = Direktorat Riset dan Pengabdian pada Masyarakat \\ HT = Hari Tanoesoedibjo \\ ITE = Information and Electronic Transactions \\ $\mathrm{KPI}=$ Komisi Penyiaran Indonesia \\ KPID = Komisi Penyiaran Indonesia Daerah \\ MNC TV = Media Nusantara Citra Televisi \\ MUI = Majelis Ulama Indonesia \\ Perindo = Partai Persatuan Indonesia \\ $\mathrm{RCTI}=$ Rajawali Citra Televisi Indonesia \\ $\mathrm{RTI}=$ Rajawali Televisi Indonesia \\ SCTV = Surya Citra Televisi \\ TPI = Televisi Pendidikan Indonesia \\ TVRI = Televisi Republik Indonesia
}

